\title{
Arthropod and Filarioid Parasites Associated with Wild Rodents in the Northeast Marshes of Buenos Aires, Argentina
}

\author{
Marcela Lareschi/ ${ }^{+}$, Juliana Notarnicola, Graciela Navone, Pedro Marcos Linardi*
}

Centro de Estudios Parasitológicos y de Vectores, Calle $2 \mathrm{~N}^{\circ}$ 584, 1900 La Plata, Buenos Aires, Argentina *Departamento de Parasitologia, ICB/UFMG, Belo Horizonte, MG, Brasil

During 1995, 16 species of arthropods and 2 species of filarioids, totaling 1287 specimens were collected from 64 wild rodents captured in the Hudson Natural Reserve, Buenos Aires, Argentina. Infestation parameters and indexes were analyzed. Host specific richness was $S=6$, diversity $H=1.48$, and relative density $R D I=40 \%$. High values of parasite species richness and diversity were found on Oligoryzomys delticola $(S=9 ; H=1.40)$, Oxymycterus rufus $(S=9 ; H=1.37)$, and Oligoryzomys flavescens $(S=9 ; H=1.28)$, followed by Scapteromys aquaticus $(S=6$; $H=0.17)$, and Akodon azarae $(S=4 ; H=1.20)$. Deltamys kempi was infested only by Androlaelaps rotundus. $\mathrm{O}$. delticola and $\mathrm{O}$. flavescens showed the highest similarity index $(O=74.19 \%)$, followed by $\mathrm{O}$. flavescens with $\mathrm{S}$. aquaticus, as a result of historical processes and shared microhabitats. Considering arthropods-filarioids associations, significant affinity was observed in Litomosoides bonaerensis with Hoplopleura travassosi, Laelaps paulistanensis, and Gigantolaelaps wolffsohni.

Key words: ectoparasitic arthropods - filarioid nematodes - diversity - rodents - Argentina

In the northeast of the Buenos Aires Province, the Hudson Natural Reserve is a biological protected area located $300 \mathrm{~m}$ from the margins of the La Plata River, Buenos Aires, Argentina. It is an ecotonal area, with the highest biodiversity of the Province (Barrios \& Moschione 1993), and is located at the southern limit of the South American subtropical humid forest. According to Cabrera and Willink (1973) it belongs to the Dominio Chaqueño, Provincia Pampeana. Wild rodents are the most representative mammals in the area (Massoia 1961), and they are associated with arthropod and helminth parasites. Currently in Argentina, the researches of parasites from rodents deal basically with systematic and morphological aspects (e.g.: Suriano \& Navone 1996, Lareschi \& Mauri 1998, Notarnicola et al. 2000), and little data has been published on parasite diversity, infestation parameters and indexes (Suriano \& Navone 1992, Lareschi 1996, Liljesthröm \& Lareschi 2002). In this study, infestation parameters and indexes of arthropod and filarioid abundance in association with wild rodents from the Hudson Natural Reserve are analyzed. In addition, host species similarity in accordance to their parasites, as well as arthropod-filarioid relationships, are studied. In this sense, the present contribution adds a new information to faunal studies of rodents and their parasites.

\section{MATERIALS AND METHODS}

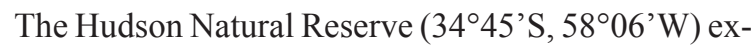
hibits a mixed landscape of grassy swamps and forested

Supported partially by UNLP, Argentina.

${ }^{+}$Corresponding author. Fax: +54-221-423.2327. E-mail: mlareschi@yahoo.com.ar

Received 9 January 2003

Accepted 5 June 2003 wetlands (Dascanio et al. 1994). It is bounded by the Selva Marginal Punta Lara Reserve on the southeast, a railroad on the west, by marshes on the northwest, and by the La Plata River on the northeast (Figure). Rodents were captured in two trapping sessions: the first on April, and the other on September 1995, and in accordance with regulations and policies of the Dirección de Administración y Difusión Conservacionista del Ministerio de Asuntos Agrarios, Buenos Aires. Captures were realized with a 7.5 $\mathrm{cm} \times 15 \mathrm{~cm} \times 8 \mathrm{~cm}$ live-trap cages using a rectangular grid with 80 trap stations ( $8 \times 10), 3$ m apart. Traps were baited with oiled bread and operated for one night at each trapping session. The rodents were killed with sulfuric ether and frozen in individual plastic bags. A voucher collection was added to the Collection of Mammals of the Museo de Ciencias Naturales de La Plata, Buenos Aires, Argentina (MLP).

The furs of the hosts were examined with a magnifying lens. Arthropods were recovered, preserved in $70 \%$ ethanol, mounted on permanent slides and identified following the conventional techniques and bibliography. Acarines and lice were identified by Lareschi, and fleas by Linardi and Lareschi. Representative ectoparasites specimens are deposited at the Entomology Collection of the MLP, and at the Department of Parasitology ICB/ UFMG, Brazil. The worms were fixed in formalin 10\%, preserved in $70 \%$ ethanol, and cleared in lactophenol for its identification by Notarnicola and Navone. These specimens were deposited at the Helminthological Collection of the MLP, and at the Museum of Natural History, Paris, France.

The following indexes and parameters were calculated for the totality of the hosts, and for each host species: Species Richness: $\mathrm{S}=$ number of species; Shannon Diversity's Index: $\mathrm{H}=-\Sigma[\mathrm{p} i \ln \mathrm{p} i]$, where $\mathrm{p} i=$ proportion of each species in the sample; Relative Density's Index: $\mathrm{RDI}=$ [number of captured rodents/number of traps] $\mathrm{x} 100$ (Begon et al. 1988); Mean Abundance: $\mathrm{MA}=$ the 


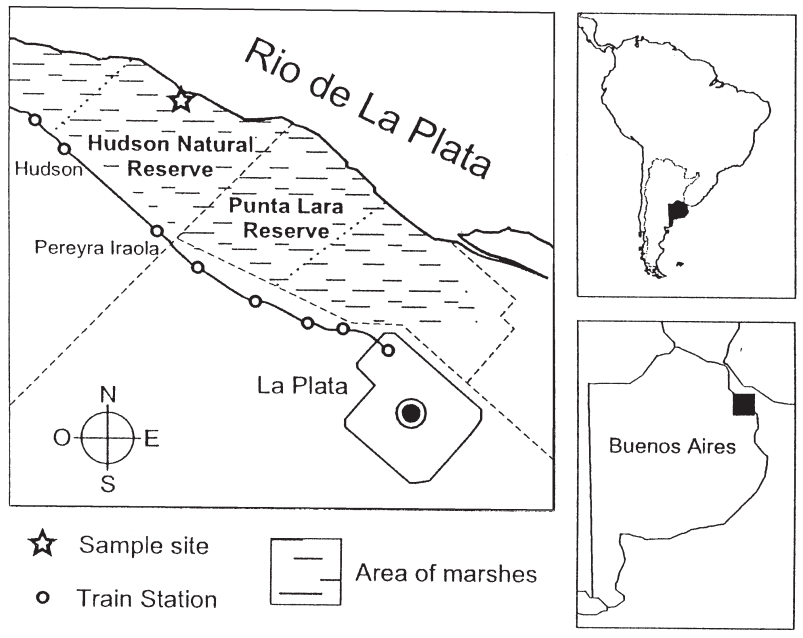

(Location) The Hudson Natural Reserve (344ㄴ 'S, 58 $\left.06^{\prime} \mathrm{W}\right)$, Buenos Aires Province, Argentina.

total number of individuals of a particular parasite species in a sample of a particular host species divided by the total number of hosts of that species examined (including both infected and uninfected host); Prevalence: $\mathrm{P}=$ the number of host infected with a particular parasite species divided by the number of host examined for that parasites species, expressed as a percentage (Bush et al. 1997).

To analyze the overlap between two host species, the Pianka's Index was calculated as follows:

$$
O=\sum p_{j} p_{k} / \sqrt{\sum p_{j}^{2} \sum p_{k}^{2}}
$$

where $p_{j}$ and $p_{k}$ are proportions of parasite species in the hosts $j$ and $k$ respectively, expressed as percentage (Pianka 1973); to the affinity within arthropods and filarioids, the Fager Affinity's Index: I $a b=2 \mathrm{~J} / \mathrm{N} a+\mathrm{N} b$, where $\mathrm{J}=$ number of hosts parasitized by the species $a$ and $b$ simultaneously; $\mathrm{N} a$ and $\mathrm{N} b=$ number of hosts parasitized by the species $a$ or $b$ respectively, the significance of this index was analyzed using Student's $t$-test $(\alpha=0.05)$ (Morales \& Pino 1987).

\section{RESULTS}

Sixty-four rodents were trapped during the study period, and 18 parasite species were collected. The host species richness and diversity index were $\mathrm{S}=6$ and $\mathrm{H}=$ 1.48 respectively, and the total relative density was $\mathrm{RDI}=$ $40 \%$. Species of rodents (Muridae: Sigmodontinae) trapped are as follows: Oxymycterus rufus (Fischer) (RDI $=18.12 \%)$, Scapteromys aquaticus Thomas $(\mathrm{RDI}=6.87 \%)$, Oligoryzomys delticola (Thomas) $(\mathrm{RDI}=6.25 \%)$, Akodon azarae (Fischer) $(\mathrm{RDI}=4.37 \%)$, Oligoryzomys flavescens (Waterhouse) $(\mathrm{RDI}=3.75 \%)$, and Deltamys kempi Thomas $(\mathrm{RDI}=0.01 \%)$. A total of 1287 parasites $(997$ arthropods, and 290 filarioids) were collected. The species of arthropods are the following: Acari, Laelapidae: Androlaelaps fahrenholzi (Berlese), Androlaelaps rotundus (Fonseca), Gigantolaelaps wolffsohni (Oudemans), Laelaps manguinhosi Fonseca, Laelaps paulistanensis Fonseca, and Mysolaelaps microspinosus Fonseca; Macronyssidae: Ornithonyssus bacoti (Hirst); Ixodidae: Ixodes loricatus Neumann; Trombiculidae: Eutrombicula alfreddugesi (Oudemans); Phthiraptera, Hoplopleuridae: Hoplopleura aitkeni Johnson, Hoplopleura fonsecai Werneck, and Hoplopleura travassosi Werneck; Siphonaptera, Rhopalopsyllidae: Polygenis (Neopolygenis) atopus (Jordan \& Rothschild), Polygenis (Neopolygenis) massoiai Del Ponte, Polygenis (Neopolygenis) frustratus Johnson, and Polygenis (Polygenis) rimatus (Jordan). The filarioids were: Nematoda, Onchocercidae: Litomosoides bonaerensis Notarnicola, Bain \& Navone, and Litomosoides oxymycteri Notarnicola, Bain \& Navone.

High values of parasite species richness and diversity were found on the following rodents: $O$. delticola $(\mathrm{S}=9$; $\mathrm{H}=1.40) ;$ O. rufus $(\mathrm{S}=9 ; \mathrm{H}=1.37)$; O. flavescens $(\mathrm{S}=9$; $\mathrm{H}=1.28) ; S$. aquaticus $(\mathrm{S}=6 ; \mathrm{H}=0.17) ;$ A. azarae $(\mathrm{S}=4$; $\mathrm{H}=1.20)$; D. kempi $(\mathrm{S}=1)$. The similarity among rodents analyzed by the Pianka's index is shown on Table I. The number of parasites, P, MA, and maximum burden (max) for every parasite species are detailed on Table II for the five representative rodents, as well as the total of these parameters. The single specimen of $D$. kempi, was parasitized by two specimens of $A$. rotundus.

The Fager's index among the arthropod species collected on $O$. rufus and the filarioid $L$. oxymycteri was not significant (Table III). However, the index among $H$. travassosi $(t=4.02)$, L. paulistanensis $(t=2.42)$, and $G$. wolffsohni $(t=2.83)$ collected on $O$. delticola with L. bonaerensis was significant. Although the prevalence of $L$. bonaerensis in $O$. delticola was almost twice that of L. oxymycteri in O. rufus.

\section{DISCUSSION}

The Natural Hudson Reserve showed higher S, H, and MA of parasites when compared to nearby localities (Lareschi 1996, Liljesthröm \& Lareschi 2002). This fact is probably due to the physonomy and to the low human

TABLE I

Index of similarity among host species from Hudson Natural Reserve, Argentina

\begin{tabular}{lcccc}
\hline Pianka index (\%) & $\begin{array}{c}\text { Scapteromys } \\
\text { aquaticus }\end{array}$ & $\begin{array}{c}\text { Oligoryzomys } \\
\text { delticola }\end{array}$ & $\begin{array}{c}\text { Akodon } \\
\text { azarae }\end{array}$ & $\begin{array}{c}\text { Oligoryzomys } \\
\text { flavescens }\end{array}$ \\
\hline Oxymycterus rufus & 0.54 & 0.26 & 1.66 & 0.09 \\
Scapteromys aquaticus & & 3.90 & 0.23 & 7.78 \\
Oligoryzomys delticola & & & 0.12 & 74.19 \\
Akodon azarae & & & 1.35 \\
\hline
\end{tabular}




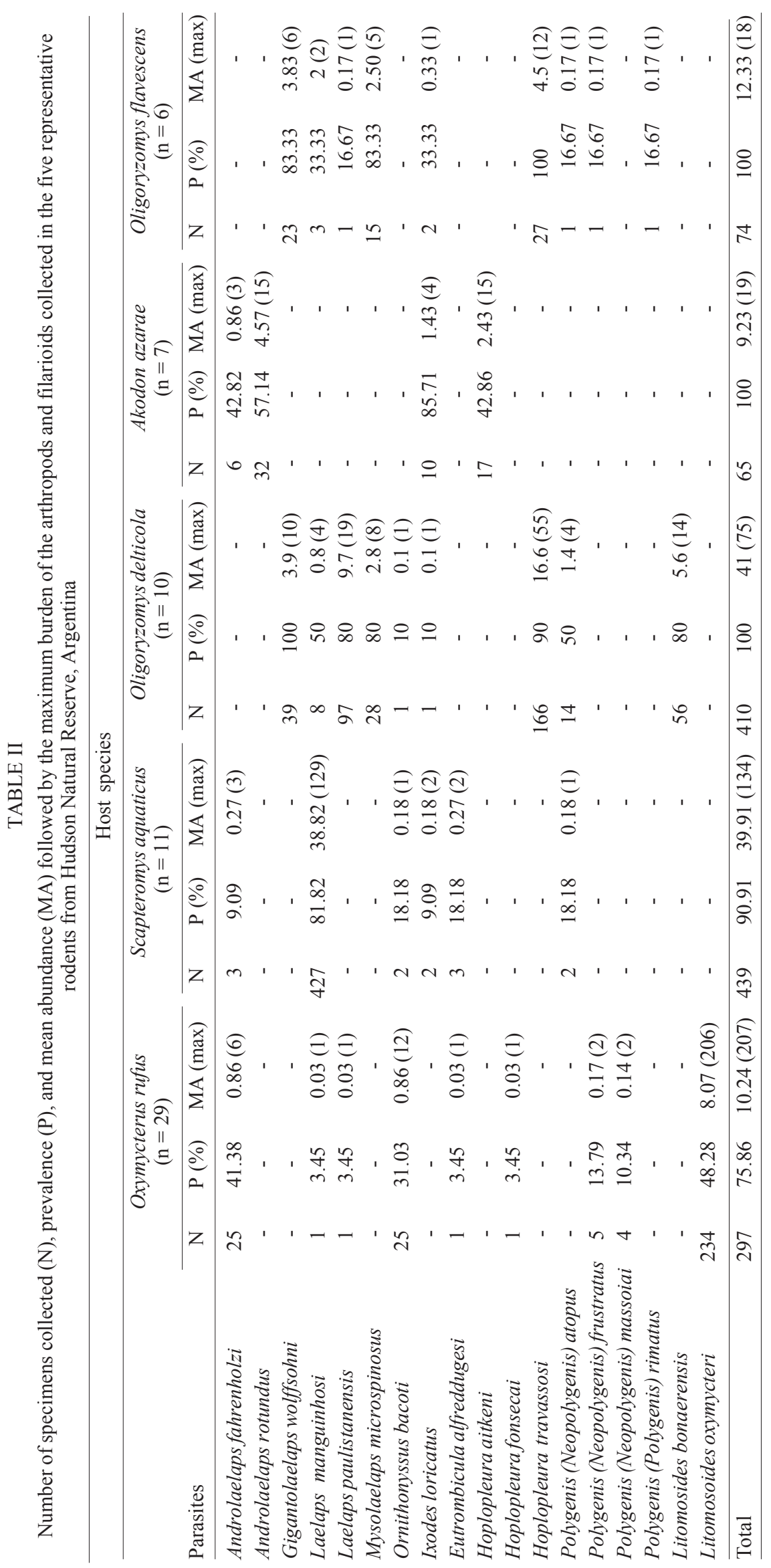


TABLE III

Fager's index of association between arthropods and filarioids from Oxymycterus rufus and Oligoryzomys delticola in Hudson Natural Reserve, Argentina

\begin{tabular}{lcccc}
\hline Filarioids & \multicolumn{2}{c}{ Litomosoides oxymycteri } & \multicolumn{2}{c}{ Litomosoides bonaerensis } \\
\hline Arthropods & FI & $T$ & FI & T \\
\hline Androlaelaps fahrenholzi & 0.30 & 0.80 & - & - \\
Gigantolaelaps wolffsohni & - & - & 0.44 & $2.83{ }^{a}$ \\
Laelaps manguinhosi & 0.07 & -1.73 & -77 & 1.60 \\
Laelaps paulistanensis & - & - & 0.44 & $2.42^{a}$ \\
Mysolaelaps microspinosus & - & 0.83 & 0.75 & -4.45 \\
Ornithonyssus bacoti & 0.22 & - & 0.22 & -1.23 \\
Ixodes loricatus & - & -1.73 & - & - \\
Eutrombicula alfreddugesi & 0.07 & -1.73 & - & - \\
Hoplopleura fonsecai & 0.07 & - & 0.94 & $4.02^{a}$ \\
Hoplopleura travassosi & - & - & 0.66 & - \\
Polygenis (Neopolygenis) atopus & - & -0.80 & - \\
Polygenis (Neopolygenis) frustratus & 0.16 & -03 & - \\
\hline
\end{tabular}

$\alpha=0.05 ; t>1.645$

disturbance in the area. The dominance of $O$. rufus is consistent with surveys of Selva Marginal Punta Lara Reserve (Kravetz 1972, Lareschi 1996). The highest value of Pianka's index was observed between Oligoryzomys species, as a result of historical processes which involve permanent parasites, such as some laelapid mites and anopluran lice (Lundqvist 1985). Moreover, those rodents, which shared the same microhabitats (e.g. Oligoryzomys spp. and $S$. aquaticus), also have high values compared to the remaining hosts. In fact, those parasite species, such as macronyssid mites, ticks, chiggers, and fleas, whose habitats are both the rodent and the rodent's microhabitat, have more opportunities to colonize other hosts which share their microhabitat (Lundqvist 1985).

The $\mathrm{S}$ of parasites was not dependent upon its intensity of infestation. O. rufus, O. delticola, and $O$. flavescens showed higher $\mathrm{S}$, meanwhile $S$. aquaticus presented the highest values of intensity of infestation. Total MA values in $O$. delticola and $S$. aquaticus were higher than in the remaining host species (Table II).

G. wolffsohni, H. aitkeni, H. fonsecai, P. (N.) massoiai, $P$. (P.) rimatus, L. bonaerensis, and $L$. oxymycteri were host specific, while the remaining parasites were associated with two or more rodents. The parasite-host association between $D$. kempi and $A$. rotundus has also been mentioned (Lareschi \& Mauri 1998). However, this is the first report that analyzed the host-parasite association at the community level.

The low MA and P reported for $H$. fonsecai are particularly important from the ecological point of view. Lareschi and Sánchez López (1999) found this sucking louse well established in Delta of the Paraná river, a northern nearby locality, infesting about $40 \%$ of the $O$. rufus, and they collected specimens in all developmental stages. In Punta Lara no specimens of $H$. fonsecai were observed, except during periods of floodings (Lareschi 1996). Taking into account that Hudson Natural Reserve is situated between both the Delta of Paraná river and Punta Lara localities, and the low abundance of $H$. fonsecai found in the present study, these results contribute to the Lareschi and Sánchez López and Lareschi's supposition (1999) that there would be a migratory flow from the Delta of the Paraná river towards Punta Lara during floodings.

Specimens of both flea subgenera, Polygenis and Neopolygenis, were collected. The latter showed higher S, MA and P in this study (Table II). Surveys from nearby localities showed similar results (Lareschi \& Iori 1998), but differ from those in Brazil, where most of the fleas which infested wild rodents belong to the subgenus Polygenis (Linardi \& Guimarães 2000).

The mite $O$. bacoti has been shown to transmit, naturally and experimentally, several species of Litomosoides (Bain et al. 1980). However, we found that this mite and the filarioids were not closely associated $(\mathrm{t}=0.83$ and 1.23; $\alpha=0.05$, Table III). On the other hand, L. bonaerensis showed significant affinities with $H$. travassosi, $L$. paulistanensis and G. wolffsohni. The former of those parasites is strictly haematophagus, and the other two probably feed facultatively on fluids or on injured skin. Considering their trophic habits, all of these ectoparasites could be vectors for the filarioids.

This report contributes to the knowledge of biodiversity of arthropods and filarioid nematodes on wild rodents, and adds information on the epidemiology of these parasites. Some of the arthropods mentioned have been shown to transmit diseases among wild and synanthropic rodents, as well as to humans (Strandmann \& Wharton 1958, Linardi \& Guimarães 2000). No specimens of Rattus were trapped in this study, in contrast to those on Punta Lara Reserve, where this rodent was present (Lareschi 1996). Despite the low anthropic perturbation, the Hudson marshy area could act as a reservoir for diseases, and nearby human settlements, such as Punta Lara, could be affected under its influence. 


\section{ACKNOWLEDGMENTS}

To María Cristina Estivariz from Cepave, for the drawing. To Carlos Galliari and Ulyses Pardiñas from Museo de Ciencias Naturales de La Plata, for determined the rodents. To Donald Gettinger from Manter Laboratory of Parasitology, University of Nebraska, US, for his critical reading of the manuscript. To Laura Gorostordoy for the critical revision of the English.

\section{REFERENCES}

Bain O, Petit G, Berteaux S 1980. Description de deux nouvelles filaires du genre Litomosoides et de leurs stades infestants. Ann Parasitol Hum Com 55: 225-267.

Barrios MI, Moschione FN 1993. Estado de conservación de los ambientes naturales de la ribera platense. Resúmenes de I Jornadas de Nacionales y VI Regionales, p. 10.

Begon M, Harper JL, Towsend CR 1988. Ecología, Individuos, Poblaciones y Comunidades, Omega, Barcelona, 886 pp.

Bush AO, Lafferty KD, Lotz JM, Shostak AW 1997. Parasitology meets ecology on its own terms: Margolis et al. revisited. J Parasitol 83: 575-583.

Cabrera AL, Willink A 1973. Biogeografía de América Latina, OEA, Washington DC, $120 \mathrm{pp}$.

Dascanio LM, Barrera M, Frangi J 1994. Biomass structure and dry matter dynamics of subtropical alluvial and exotic Ligustrum forest at the Río de la Plata, Argentina. Vegetatio 115: 61-76.

Kravetz FO 1972. Estudio del régimen alimentario, períodos de actividad y otros rasgos ecológicos en una población de "ratón hocicudo" (Oxymycterus rufus platensis Thomas) de Punta Lara. Acta Zoologica Lilloana 29: 201-212.

Lareschi M 1996. Estudio preliminar de la comunidad de roedores (Rodentia: Muridae) y sus ectoparásitos (Acari, Phthiraptera y Siphonaptera) en Punta Lara (Buenos Aires). Rev Soc Entomol Argent 55: 113-120.

Lareschi M, Iori A 1998. Nuevas citas de Siphonaptera (Rhopalopsyllidae; Hystrichopsyllidae) parásitos de roedores de la provincia de Buenos Aires, Argentina. Rev Bras Entomol 41: 165-168.

Lareschi M, Mauri R 1998. Dermanyssoidea. In JJ Morrone, S Coscarón (eds), Biodiversidad de Artrópodos Argentinos.
Una Perspectiva Biotaxonómica, Ediciones Sur, La Plata, p. 581-590.

Lareschi M, Sánchez López MI 1999. Estudio del parasitismo de Hoplopleura fonsecai Werneck (Phthiraptera: Hoplopleuridae) sobre Oxymycterus rufus en el delta del Río Paraná, Argentina. Neotropica. 45: 109-110.

Liljeström G, Lareschi M 2002. Estudio preliminar de la comunidad ectoparasitaria de roedores sigmodontinos en el partido de Berisso, provincia de Buenos Aires. In D Salomón, Actualizaciones en Artropodología Sanitaria Argentina. Edición Fundación Mundo Sano, Bue-nos Aires, p. $257-260$.

Linardi PM, Guimarães LR 2000. Sifonápteros do Brasil, MZUSP, Fapesp, São Paulo, 291 pp.

Lundqvist L 1985. Life Tactics and Distribution of Small Mammals Ectoparasites (Anoplura, Siphonaptera and Acari) in Northernmost Fenoscandia, PhD Thesis, Dept Anim Ecol, Univ of Lund, Sweden, 99 pp.

Massoia E 1961. Nota sobre cricétidos de la selva marginal de Punta Lara. Publ Mus Mem Cs Nat Mar del Plata 1: 115-134.

Morales G, Pino LA 1987. Parasitología Cuantitativa, Fundación Fondo Editorial, Acta Científica Venezolana, Caracas, 132 pp.

Notarnicola J, Bain O, Navone GT 2000. Two new species of Litomosoides (Nematoda: Filarioidea) in sigmodontines (Rodentia: Muridae) from Río de la Plata marshland, Argentina. J Parasitol 86: 1318-1325.

Pianka E R 1973. The structure of lizard communities. Annual Rev Ecol Syst 4: 53-74.

Strandtmann RW, Wharton GW 1958. Manual of Mesostigmatid Mites, Contribution no. 4 of The Institute of The Acarology CE Yunker, 330 pp.

Suriano DM, Navone GT 1992. Systematic and ecology of Stilestrongylus freitasi Durette-Desset, 1968 and Hassalstrongylus multiovatus n. sp. (Nematoda: Nippostrongylinae) from Akodon simulator (Cricetidae) in Tucumán (Argentina). Res Rev Parasitol: 52: 51-55.

Suriano DM, Navone GT 1996. Stilestrongylus scapteromys n. sp. (Nematoda) from Scapteromys aquaticus Thomas (Rodentia: Cricetidae) from the marginal forest of Punta Lara (Buenos Aires, Argentina). Physis (Buenos Aires) 51: 25-29. 